\title{
Learning leadership in outdoor education: Effects of feedback
}

\author{
Åge Vigane \& Sindre M. Dyrstad \\ University of Stavanger, Norway
}

\begin{abstract}
There is paucity of knowledge regarding learning outcomes from outdoor leadership training courses. The aim of this pilot study was to examine progress in perceived leadership skills after a six-month outdoor education course, and to examine the effect of systematic feedback from fellow students. Seventeen students were randomized into intervention and control groups and participated in six outdoor excursions during which they took leader roles. The intervention consisted of systematic use of feedback from fellow students. To assess the progress in students' perceived outdoor leadership skills, the students answered a questionnaire covering four categories of leadership both before and after the course. Significant progress in perceived outdoor leadership was found for all students after the six-month course. Systematic feedback from fellow students did not seem to enhance students' perceived outdoor leadership skills. The reasons could be that the feedback was not given in the actual situations or that the student feedback was not valued. Feedback from teachers and from nature (self-experience) were found to be important for strengthening perceived leadership skills.
\end{abstract}

Keywords: outdoor leadership; situation-oriented learning; friluftsliv; feedback; fellow students

Received: March, 2021; Accepted: October, 2021; Published: January, 2022

\section{Introduction}

One of the primary aims of outdoor education courses in higher education is to create competent outdoor leaders (Martin et al., 2006, p. ix; Priest \& Gass, 2018, p. 10). One way to achieve this is by helping students develop self-management and autonomy (Faarlund, 2003, pp. 44-45; Tordsson, 2014, p. 259). Examining students' perception of their outdoor leadership skills can be one way to assess progress towards competence in outdoor leadership. Reflection, feedback, autonomy, real situations, self-support, and agency are often highlighted in literature to support diverse learning processes (Beames \& Brown, 2016, p. 101; Norton et al., 2011; Vikene et al., 2019 , p. 107), and are central in experiential learning theory. Experiential learning

^Correspondence: Åge Vigane, e-mail: age.vigane@uis.no

(C) 2022 A. Vigane \& S. M. Dyrstad. This is an Open Access article distributed under the terms of the Creative Commons Attribution 4.0 International License (https://creativecommons.org/licenses/BY/4.0/), allowing third parties to copy and redistribute the material in any medium or format and to remix, transform, and build upon the material for any purpose, even commercially, provided the original work is properly cited and states its license.

Citation: A. Vigane $\mathcal{E}$ S. M. Dyrstad. "Learning leadership in outdoor education: Effects of feedback» fournal for Research in Arts and Sports Education, Special issue: Friluftsliv, dannelse, lering og didaktikk, Vol. 6(1), 2022, pp. 108-121. http://dx.doi.org/10.23865/jased.v6.2969 
has been the educational philosophy and pedagogical approach in outdoor education programs internationally for decades (Martin et al., 2017, pp. 23-24; Priest \& Gass, 2018, pp. 36-45). Dewey (1938) and Kolb (1984) in Priest and Gass (2018, p. 41) underline the importance of solving problems by reflecting on experiences in real situations, and by developing new knowledge and competence as a result of that reflection. Small groups are important to enhance all the group members' leadership experience, and because students are less afraid to try to lead when there are fewer people (aka critics, dissenters) than when the group is large. The term "friluftsliv" (literally: "free air living") is common Norwegian vernacular and refers to time spent in nature doing non-motorized activities like hiking, backcountry skiing, camping, fishing or similar. Friluftsliv is very popular in Norway and there are numerous programs available that teach outdoor leadership skills geared towards guiding people in friluftsliv experiences. However, there are limited studies examining the effectiveness of such programs (Enoksen \& Lynch, 2018; Vikene et al., 2019, p. 108), and no studies describing the perceived progression in outdoor leadership skills have been found.

Therefore, the purpose of this study was to examine: (1) to what extent students improved perceived leadership skills after a six-month outdoor education course, and (2) to what extent systematic use of peer feedback (fellow students), in addition to feedback from teachers, strengthened perceived outdoor leadership skills.

We expected all students to improve their perceived leadership skills, with the students in the intervention group showing the most progress.

\section{Learning to be leaders}

\section{Core competencies of outdoor leadership}

Outdoor leadership requires a wide range of skills, including technical, organizational, self-management, judgement and decision-making, and interpersonal skills. In outdoor leadership courses, it is common to classify outdoor leadership into hard or soft skills. Hard skills are technical competencies such as rope handling for rock climbing, lead climbing on ice, kayaking white water and kayak rescues. Students are regularly assessed for hard skills in outdoor leadership programs. Soft skills, such as decision-making, judgement, and group relations in the field, are also commonly assessed (Graham, 1997, pp. 9-13; Martin et al., 2017, p. 5; Priest \& Gass, 2018, pp. 114-125). Regarding hard or soft skills, most theories on leadership assume that leadership is a complex relationship between the leader and the context in which the leader is engaged (Graham, 1997, p. 12; Martin et al., 2017, pp. 5, 19; Priest \& Gass, 2018 , p. 22). Leadership can be seen as a process driven by a person's intention to influence, or to help a person or group to achieve goals they would not achieve by themselves (Graham, 1997, p. 12; Yukl, 2013, p. 18).

Yukl (1989, pp. 35, 59-60) describes four categories of leadership behaviour. These leadership behaviours are, in a pedagogical context, important for teaching students how to facilitate learning in an outdoor context. First, the giving-seeking information 


\section{Å.Vigane $\mathcal{G}$ S. M. Dyrstad}

category includes components that relate directly to communication skills (Sibthorp et al., 2007), teaching and facilitation (Martin et al., 2017, p. 5), instructional and facilitation skills and effective communication (Priest \& Gass, 2018, p. 13). Second, the making decisions category is ubiquitous in management, leadership, as well as outdoor leadership literature. A major concern for outdoor leaders in making decisions is judgement, a skill honed by honest reflection on experience. According to several studies (Enoksen \& Lynch, 2018; Faarlund, 2003, pp. 48-50; Graham, 1997, pp. 10-11) leaders need judgement for social as well as physical problem solving and decision making. Third, a pedagogical leader needs the ability to influence people. Having a flexible leadership style (Priest \& Gass, 2018, pp. 218-222) and being selfaware of personal conduct and professional ethics (Martin et al., 2017, pp. 6, 56-58; Priest \& Gass, 2018, pp. 14, 59-64) are skills that enable a leader to influence other people. Fourth, building relationships includes supporting, networking, managing conflict, and teambuilding, all skills needed for working with behaviours within small groups. Faarlund (2003, pp. 46-48) underlines the value of small groups and agency to build good relations, Sibthorp (2003) refers to verbal feedback from peers and leaders, and Graham (1997, pp. 66, 108, 122) the importance of caring, resolving conflicts and teambuilding. Yukl's four categories, shown in Figure 1, are later elaborated as leadership behaviours, like task-oriented behaviours and relations-oriented behaviours (Yukl, 2010, p. 107, 2013, p. 64).

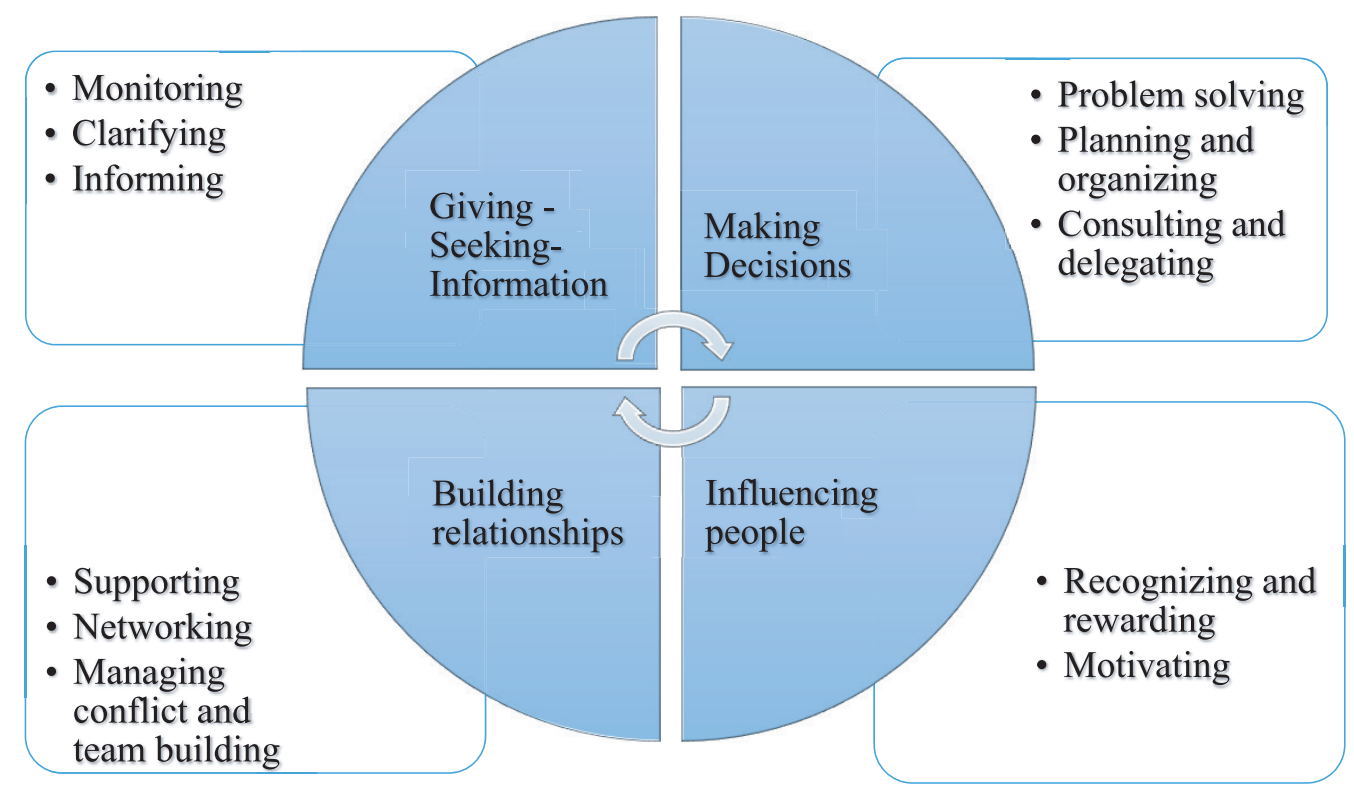

Figure 1. An adapted version of Integrating Taxonomy of Managerial Behaviour (Yukl, 1989, pp. 35, 59-60), describing four categories of leadership behaviours, each exemplified by two or three subcategories. 
In Norway, $79 \%$ of the population above 16 years of age spend time hiking in forests or mountains, and hiking is the most common outdoor activity in Norwegian daily life (Statistic Norway, 2020). Hiking in Norway stems from two $18^{\text {th }}$ century traditions, harvesting and mountaineering. Part of the Norwegian identity has roots in the self-sufficient mountain farmers, who were role models in being selfsupported, free, and able to handle the challenges of living in, and of, nature (Tordsson, 2014, pp. 37-40; Vigane \& Sæther, 2020, p. 17). Having good outdoor leaders leading groups of people into nature to continue these national traditions is therefore important in Norwegian society.

The literature cited above on leadership behaviour provides a conceptual framework for assessing progress in outdoor leadership development. This conceptual framework is used in Outdoor Education at University of Stavanger and was used for the pre- and post-course questionnaire for the present study.

\section{Learning Outdoor Leadership}

Situated learning (Faarlund, 2003, pp. 43-46; Tannenbaum \& Schmidt, 1973; Vikene et al., 2019, pp. 112-113, 121) underlines the importance of being active and engaged and learning from real situations. Situated learning in a community of practice is also supported by Høyem (2010, p. 76). By giving students the task of making a snow cave, for example, the teacher facilitates students' learning to solve real problems in a meaningful situation. For an experience to be educative, Dewey (1938, p. 39) theorized that it must provoke a thirst for further learning, and it must connect meaningfully to the "objective conditions of the learner's life". Wenger (2004, p. 24) interprets objective conditions as four key components of situation-oriented learning: First, learning activities should be contained within a meaningful context. Second, learning takes place in a community where the learners accept affiliation. Third, practice-based activities must be as realistic as possible. Fourth, situated learning will eventually affect the learner's identity.

Tordsson (2014, p. 17) similarly views friluftsliv as a practice that has natural (situational), implemented (action), and pedagogical (understanding) elements, and these three elements are deeply interconnected. To become a good outdoor leader, experience from different situations in the practice field is essential (Vikene et al. (2019, pp. 115-116). The active role and responsibility of students in both the planning and decision-making processes and in small group behaviour, is also underlined by Sibthorp (2003), and Sibthorp et al. (2007).

Faarlund (1974, pp. 86-87), and Tordsson (2014, pp. 218-219, 245-249) both underline the importance of pedagogical aspects for agency and self-management in planning, implementation, and evaluation. By organizing students into small groups giving them responsibility like leading in turn, we facilitate for student-led engagement. 


\section{Å.Vigane $\mathcal{G}$ S. M. Dyrstad}

In the present study, feedback from fellow students and feedback from teachers during excursions focused on leadership decisions made by students when in the leader role. The students made leadership decisions in areas such areas as orientation, finding a safe route in avalanche terrain, how to teach other students to make a snow cave or igloo, fishing, tying appropriate knots and teaching children. The students had to solve real problems in small groups with three others.

\section{Reflection and feedback as tools for developing outdoor leadership}

Dewey (1938, pp. 68-69) theorized that learning occurs when a purpose for learning is formed, which involves observation, knowledge from external sources and from past experience, as well as judgement. This "complex intellectual operation" has been interpreted as the heuristic reflection in much of the experiential education literature. Reflection on action is widely referenced and adapted in experiential learning and outdoor education (Martin et al., 2017, p. 213; Priest \& Gass, 2018, pp. 40-41). Reflection on action is central to this study because reflection on feedback from fellow students can help boost leadership skills. Reflection is "an in-depth consideration of events or situations; the people involved, what they experienced, and how they felt about it" (Bolton, 2010, p. xix). Feedback has been defined as "information provided by an agent (e.g., teacher, peer, book, parent, self, experience) regarding aspects of one's performance or understanding" (Hattie \& Timperley, 2007, p. 81)

In the Scandinavian tradition of learning by doing, inductive learning and problem-based learning are all well-accepted ways to facilitate learning (Vikene et al., 2019, pp. 121-122). In learning related to friluftsliv, which occurs in natural environments, students receive feedback from nature (self-experience). According to Hattie and Timperley (2007, pp. 86-87), students can develop strategies and regulate performance to reach goals by self-regulation. When new, unexpected situations occur, learners have to use creativity to solve problems (Beames \& Brown, 2016, p. 74). Recognizing patterns and reflecting upon choices and decisions are important to learning (Tordsson, 2014, p. 263). Feedback can help a student overcome perceived limitations and help them discover unknown personal leadership resources instead of resist efforts to develop leadership skills (Priest \& Gass, 2018, pp. 284, 301). In outdoor education at the University of Stavanger, feedback typically focuses on how students reflect on their decisions, how they seek and give information in a group, how they manage intra-group relationships, and how they act as good role models so the people they lead can be inspired and influenced by them. This approach is consistent with that of Paul Petzoldt, founder of National Outdoor Leadership School in USA. According to Wagstaff and Cashel (2008, p. 129), Petzoldt proposed that feedback in judgement and decisionmaking skills is a core element in outdoor leadership. The importance of facilitating 
for decision-making is supported by studies by Høyem (2010), Faarlund (2003, pp. 46, 49) and Hallandvik et al. (2017), which was conducted in a Norwegian outdoor leader education context.

\section{Methods}

\section{Design and participants}

This pilot study had a randomized controlled trial design and was approved by The Norwegian Centre for Research Data. The participants were students taking 30 ECTS (study points) in Outdoor Education in their $2^{\text {nd }}$ year of the bachelor program in Sports Science at the University in Stavanger. Twenty out of 24 students gave their written informed consent to participate, and 17 students completed both the pre- and post-intervention questionnaires. Thirteen students were male and 4 were female.

The participants were randomized into an intervention group $(n=12)$ or a control group $(n=8)$. To maximize practice and learning, students were randomly divided into three groups of four in the intervention group and two groups of four in the control group. The 6 international students were less experienced in winter outdoor life than the Norwegian students. Therefore a maximum of two international students per group was set to ensure safety and competence in each of the groups. This group size (4 students per group) was optimal with respect to performing learning activities such as making a snow cave, navigation, planning, organizing and leading excursions. Due to incomplete questionnaires, two students in the intervention group and one student in the control group were excluded.

The students' prior experience in the outdoors differed widely. Some of the international students had little or no experience in outdoor activities and skiing. Other students had spent time in the Norwegian Army and the Scouts, which includes spending long periods of time outdoors in the mountains in winter.

\section{The intervention}

The six-month intervention period included six excursions lasting from three to six days each: two teacher-led winter excursions, one student-led winter excursion, one student-led biking excursion, one teacher-led fishing excursion and one teacher-led hiking excursion. In addition, students taught outdoor activities in a forest to young students from a local school for about two weeks. Both the intervention group and the control group participated in all six excursions.

During the two student-led excursions, no teachers participated, and students were responsible for planning, organizing and leading fellow students. In the four 


\section{Å.Vigane $\mathcal{G}$ S. M. Dyrstad}

teacher-led excursions, teachers primarily observed and gave feedback to all the student groups, while students in turn led their own group of four students during the teaching activities.

The intervention group was instructed to use systematic feedback while the control group was not given any formal instructions regarding giving feedback to fellow students. In both the intervention group and control group, feedback could be given during the day. For the intervention group, systematic feedback included observing the leader student closely and taking feedback notes during excursions and during the two weeks of teaching outdoor activities. They were expected to compile their notes into written feedback using a feedback form. This process was completed for each student leader in the group. The feedback form was based on Yukl's four categories of leadership behaviour, customized for outdoor leadership. The feedback was shared during a feedback meeting within two days after returning from the excursion. The agenda of the feedback meeting was to sum up, share and reflect upon their observations and written feedback regarding the four leadership behaviour categories in the context of outdoor leadership.

\section{Questionnaire}

To assess the outdoor leadership skills of the students, a questionnaire based on Yukl's classification of leader behaviour (1989, pp. 35, 59-60) was created. As shown in Figure 1, the four categories of leader behaviour are broken down into subcategories. To assess students' competence, 30 questionnaire items were developed based on Yukl's definitions of the subcategories, as well as the specific activities at excursions. Table 1 provides an overview of the 30 items.

To classify students' perceived outdoor leadership behaviour, students evaluated their level of competence for each leadership behaviour before and after the intervention period using a Likert scale from 1-10, modified by the model from Dreyfus and Dreyfus (1980, p. 15). This scale illustrates the level of outdoor leadership: a score of 1-2 indicates novice, 3-4 indicates advanced beginner, 5-6 indicates competent, 7-8 indicates proficient and 9-10 indicates an expert (Table 1). A similar questionnaire and Likert scale was used by Dale and Wrisberg (1996) in assessing behaviour in sport. The questionnaire in this study was tested and adjusted based on feedback from other students and colleagues before being used in the pilot study.

The questionnaire was answered online before and after the intervention period (January and June), and students used around $30 \mathrm{~min}$ on the questionnaire each time. By comparing responses from January and June, progress in perceived leadership skills was measured. 
Table 1. Items in the self-assessment questionnaire based on Yukl's categories of leader behaviour (1989, pp. 35, 59-60)
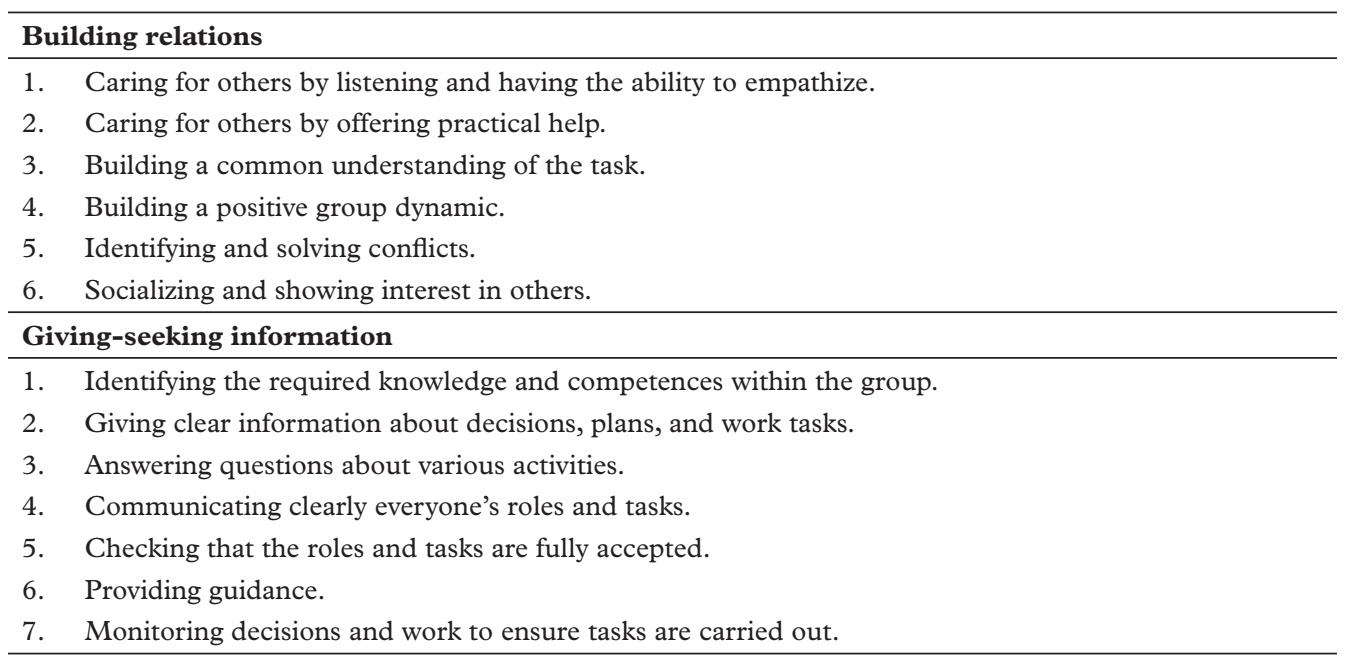

\section{Influencing people}

1. Acting as a role model.

2. Encouraging a positive attitude to all participants.

3. Encouraging participants to help and support each other.

4. Encouraging participants to do as well as they can.

5. Giving praise and recognition at the right time and in the right situation.

6. Showing respect and appreciation for the effort of others.

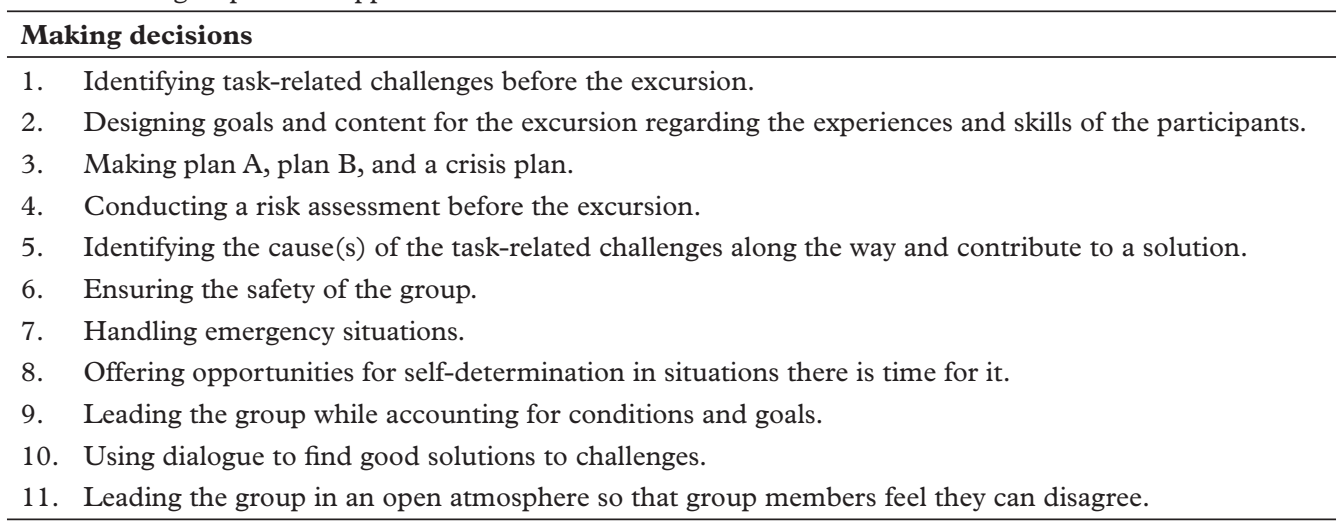

\section{Statistics}

Variable values are presented as mean (standard deviation: $S D$ ). The scores from all subcategories in each main category were summed and divided by the number of subcategories in each category and are shown in Table 2. Cronbach's alpha was used to assess the internal consistency of outdoor leadership and its four main categories included subcategories. Building relations, giving-seeking information, influencing people and making decisions all had high reliabilities (Cronbach's alpha $\geq 0.78$ (Table 2). The correlations between the four categories were between 0.53 and 0.89 


\section{A. Vigane E S. M. Dyrstad}

for both pre- and post-intervention questionnaires. A paired sample $t$-test was used to detect differences between the mean sum from the pre- and post-intervention questionnaire for each of the four categories of leadership behaviour. An independent sample t-test was used to detect difference in the change, for each of the four categories of leadership behaviour, between the intervention and control group. A p $<0.05$ was regarded as statistically significant.

Table 2. Cronbach's alphas for the four categories of outdoor leadership

\begin{tabular}{lccc}
\hline Main category & \multicolumn{2}{c}{ Number of sub-categories } & \multicolumn{2}{c}{ Reliability Cronbach's alpha } \\
\cline { 3 - 4 } & & Pre & Post \\
\hline Building relations & 6 & 0.84 & 0.88 \\
Giving-seeking information & 7 & 0.95 & 0.95 \\
Influencing people & 6 & 0.92 & 0.96 \\
Making decisions & 11 & 0.91 & 0.78 \\
\hline
\end{tabular}

\section{Results}

A significant improvement of $23-40 \%$ in perceived competency in the four outdoor leadership behaviours was found both in the intervention and the control group (Table 3). Perceived progress in making decisions had a significantly larger increase than the other three behaviours. No significant difference in change in perceived leadership skills were found between the intervention and control group ( $\mathrm{p}$-values between 0.2 and 0.9 ).

Table 3. Changes from pre-intervention (January) to post-intervention (June) in perceived competence in each of the four categories in outdoor leadership behaviour in the intervention and control group. Data is presented as mean (standard deviation), and the score is from 1 (lowest grade of competence) to 10 (highest grade of competence).

\begin{tabular}{|c|c|c|c|c|c|c|c|c|c|c|}
\hline & \multicolumn{3}{|c|}{$\begin{array}{c}\text { Intervention group } \\
\qquad(n=10)\end{array}$} & \multicolumn{3}{|c|}{$\begin{array}{c}\text { Control group } \\
(n=7)\end{array}$} & \multicolumn{4}{|c|}{ All $(n=17)$} \\
\hline & Pre & Post & $\begin{array}{l}\text { Change } \\
\text { score }\end{array}$ & Pre & Post & $\begin{array}{c}\text { Change } \\
\text { score }\end{array}$ & Pre & Post & $\begin{array}{c}\text { Change } \\
\text { score }\end{array}$ & $\begin{array}{c}\text { Change } \\
\%\end{array}$ \\
\hline $\begin{array}{l}\text { Building } \\
\text { relations }\end{array}$ & $\begin{array}{c}6.3 \\
(1.3)\end{array}$ & $\begin{array}{c}7.8 \\
(0.7)^{\star}\end{array}$ & $\begin{array}{c}1.5 \\
(1.2)\end{array}$ & $\begin{array}{c}6.9 \\
(0.6)\end{array}$ & $\begin{array}{c}8.4 \\
(1.0)^{\star}\end{array}$ & $\begin{array}{c}1.5 \\
(0.8)\end{array}$ & $\begin{array}{c}6.6 \\
(1.1)^{\star}\end{array}$ & $\begin{array}{c}8.1 \\
(0.8)^{\star}\end{array}$ & $\begin{array}{c}1.5 \\
(1.0)^{\star \star}\end{array}$ & $22.7 \%$ \\
\hline $\begin{array}{l}\text { Giving- } \\
\text { seeking } \\
\text { information }\end{array}$ & $\begin{array}{c}6.2 \\
(1.2)\end{array}$ & $\begin{array}{c}7.6 \\
(0.7)^{\star}\end{array}$ & $\begin{array}{c}1.4 \\
(1.5)\end{array}$ & $\begin{array}{c}6.2 \\
(1.4)\end{array}$ & $\begin{array}{c}8.6 \\
(1.2)^{\star}\end{array}$ & $\begin{array}{c}2.4 \\
(1.4)\end{array}$ & $\begin{array}{c}6.2 \\
(1.3)^{\star}\end{array}$ & $\begin{array}{c}8.0 \\
(1.0)^{\star}\end{array}$ & $\begin{array}{c}1.8 \\
(1.5)^{\star \star}\end{array}$ & $29.0 \%$ \\
\hline $\begin{array}{l}\text { Influencing } \\
\text { people }\end{array}$ & $\begin{array}{c}6.1 \\
(1.4)\end{array}$ & $\begin{array}{c}7.6 \\
(1.1)^{\star}\end{array}$ & $\begin{array}{c}1.5 \\
(1.2)\end{array}$ & $\begin{array}{c}6.9 \\
(0,9)\end{array}$ & $\begin{array}{c}8.4 \\
(1,4)^{\star}\end{array}$ & $\begin{array}{c}1.5 \\
(1.3)\end{array}$ & $\begin{array}{c}6.4 \\
(1.3)^{\star}\end{array}$ & $\begin{array}{c}7.9 \\
(1.2)^{\star}\end{array}$ & $\begin{array}{c}1.5 \\
(1.2)^{\star \star}\end{array}$ & $23.4 \%$ \\
\hline $\begin{array}{l}\text { Making } \\
\text { decisions }\end{array}$ & $\begin{array}{c}5.4 \\
(1,2)\end{array}$ & $\begin{array}{c}7.6 \\
(0,6)^{\star}\end{array}$ & $\begin{array}{c}2.2 \\
(1.3)\end{array}$ & $\begin{array}{c}5.6 \\
(1.1)\end{array}$ & $\begin{array}{c}7,9 \\
(1.4)^{\star}\end{array}$ & $\begin{array}{c}2.3 \\
(1.4)\end{array}$ & $\begin{array}{c}5.5 \\
(1.1)^{\star}\end{array}$ & $\begin{array}{c}7.7 \\
(0.9)^{\star}\end{array}$ & $\begin{array}{c}2.2 \\
(1.3)^{\star \star}\end{array}$ & $40.0 \%$ \\
\hline
\end{tabular}

$\star$ Significant different from pre-intervention $(p<0.05)$

$\star \star$ Significant different from pre-intervention $(p<0.001)$ 


\section{Discussion}

The main finding of the study was a significant improvement in perceived competence in the four outdoor leadership behaviours for all students during a six-month outdoor education course. No differences in change between the intervention and control groups were found. The largest improvement in outdoor leadership was found in the making decisions behaviours. We assume the effect of agency, small group dynamic, learning from teachers in real situations, self-experience feedback from nature and student-led excursions, all contributed to perceived improvement in outdoor leadership. The pedagogical approach, like facilitating for responsibility, consequences of actions and inviting students to lead by turn, seemed to have a great impact on students' perception of their skills in making decisions. Another reason for the large progression can be that the students had little experience in making decisions in a group context before they started the program. Through the activities and challenges during the excursions, and the organization of students into small groups, students were placed in real situations where they had to lead others and make decisions. According to Dewey (1938, pp. 68-69) and Beames and Brown (2016, pp. 108-110), it seems that agency, large responsibility, and ability to apply have a large impact on all students' perception of their leadership behaviour. This is supported by Vikene et al. (2019, pp. 121-125) and Sibthorp et al. (2007), who underline the importance of making students responsible for decision making. Further, Wenger (2004, p. 285) concludes that involvement and participation in a community of practice enhance the learning outcomes for everyone. Both the intervention and control groups were given expansive responsibility in planning and organizing student-led excursions during the outdoor education course. Based on the teaching in leadership theory, the excursions and practice during the course and how students' decisions and judgement directly influenced well-being, it was expected that all students' perceived leadership skills would progress. Because the present study is the first Norwegian study examining perceived progression in outdoor leadership skills among students, it is difficult to evaluate the importance of the $23-40 \%$ improvement in the four soft-skills leadership categories. However, by practicing decision making in a variety of situations, the students feel safer and more comfortable when making decisions.

A surprising finding was that results showed no significant difference in perceived leadership skills between the intervention and the control group. One reason could be that the systematic feedback from fellow students was given one or two days after the end of the excursion rather than during the excursion. This delay might have reduced the learning. One reason systematic feedback from fellow students was given after the excursion and not on a daily basis was that weather conditions were often challenging. In situations with cold, wind and exhausting tasks (e.g., digging a snow cave and igloo), systematic feedback during the day was hard to prioritize. Students also reported that they were too tired to share feedback at the end of the day. Since the intervention and the control groups showed the same improvement in perceived leadership competence, experiences in the field related to concepts described by 


\section{Å.Vigane $\mathcal{G}$ S. M. Dyrstad}

Hattie and Timperley (2007, p. 87), the value of self-experience feedback (Høyem, 2010; Vikene et al., 2019, pp. 108-109, 121), and the importance of situated learning, can explain the progression among all the students. In addition, conversations with students from the intervention group after the intervention was finished revealed that students found the feedback form too complex, and stated that it was hard to give concrete feedback to increase learning. This suggests that the systematic peer feedback as organized in the present study was not important for the increase in perceived leadership skills. These findings are supported by Paisley et al. (2008), who found feedback did not play a major role in learning.

In the opposite, Carver (2008, p. 152) and Beames and Brown (2016, pp. 29, 33) underline that concrete and situation-oriented feedback will strengthen the learning process. It might be that systematic and spontaneous feedback given during tasks in the smaller student group might be more effective and better for learning than systematic feedback given at the end of the day or after the excursion? However, giving this kind of feedback could be difficult for inexperienced outdoor education students. The above literature does not distinguish between peer feedback and teacher feedback, but Hattie (2012, p. 25) concluded that focused feedback from teachers is important in the learning process. Students in both the intervention group and the control group received systematic and spontaneous teacher feedback during the excursions with approximately the same scope and depth. In addition, nature probably spoke loud and clear to all the students about how to stay safe and comfortable in different situations. Feedback from wind, temperature, snow conditions, equipment and body will in real situations have a great influence and enhance learning in outdoor leadership.

The feedback and teaching from teachers, and feedback from nature, was probably more impactful than feedback from peers. For example, to teach students how to make a safe route selection, the teachers gathered the group close to an appropriate upward hill. Then teachers asked questions about how to assess the risk of avalanche by checking steepness, prevailing wind direction, recent temperature changes, snow conditions, size of snow crystals, existence of small cracks in the snow and rumble/ sounds from the snow. By solving problems in a real situation, which could cause injury or risk for avalanche, the students probably learned a lot from teachers and nature, because they were focused and concentrated on the learning outcome, and because the consequences were very real. The following example explains how nature gave feedback to students regarding route selection, clothing, equipment and decision making: After leading for approximately $7 \mathrm{~km}$, the student leaders were planning for a break. They decided to stop on top of a windy hill. After the uphill hike, all the students were sweaty. As the cold $\left(9^{\circ} \mathrm{C}\right)$, windy conditions chilled their bodies, amplified by the sweat, the students quickly understood that this was not a good location for a break. They were learning along the way, because nature taught them to avoid the cold and uncomfortable situations. Nature might therefore be the best at teaching outdoor leadership skills. 
How did we define progress in the four categories of soft leadership skills? First, progression in perceived leadership behaviour, especially decision making, is measurable. By keeping the groups small, allowing expansive agency, and providing a multitude of decision-making opportunities during excursions and activities, leader students got plenty of decision-making practice in a safe space. Second, the students seemed to be more conscious of their interpersonal skills, and the value of influencing others. Attentiveness to how one's behaviour can influence others is important for outdoor leadership. Third, by recognizing the importance of interpersonal skills, giving and seeking information and understanding how to influence others, the students can more effectively teach others technical skills. Finally, the results show that teachers and nature strongly influence progress in outdoor leadership, compared to feedback from peers. There are weaknesses in how the systematic feedback was organized, as well as weaknesses in the descriptions of the different levels of leadership (novice, advanced beginner, competent, proficient, expert) according to Dreyfus and Dreyfus (1980, p. 15). However, the findings can provide the basis for more research into how students learn, and what they learn at university studies in outdoor education.

\section{Limits of the study}

This is a pilot study and contains a small number of participants. Therefore, a full factor analysis could not be carried out to validate the Norwegian questionnaire. However, the internal consistency within the four categories of leadership behaviour showed high reliabilities with Cronbach's alphas $\geq 0.78$, and all correlations between the four categories of leadership behaviour within the recommended values between 0.3 and 0.9 (Field, 2013, p. 694). Even though the results could not be generalized, significant findings and useful experiences regarding how student feedback could be carried out could form the basis for new studies examining use of systematic student feedback in outdoor education.

Second, self-assessments have limitations. A comment from one student highlights this dilemma. She thought she had overestimated herself at the beginning of the semester and said: "The more experience I get, the more I realize I didn't know as much as I thought". Comparison with teacher assessments could be one way to account for gross over- or under-estimations.

\section{Conclusion}

The purpose of this study was to examine: (1) to what extent students improved perceived leadership skills after a six-month outdoor education course, and (2) to what extent systematic use of feedback from fellow students, in addition to feedback from teachers, strengthened perceived outdoor leadership skills. All students experienced a significant positive development in perceived outdoor leadership skills. 


\section{Å.Vigane $\mathcal{G}$ S. M. Dyrstad}

Results indicate that systematic feedback from fellow students given after excursions did not strengthen perceived leadership skills. This could be a result of the peer feedback form being too complex, peer feedback being given too late after the activity, or peer feedback given in too general terms. Feedback from teachers and feedback from nature in real situations seem to explain students' strong progress in perceived outdoor leadership skills. The results underline the important role teachers play in giving real time feedback to students during excursions, the importance of agency, and the importance of teachers facilitating learning by experience in real situations.

\section{Author biographies}

Åge Vigane is an associate professor in physical education, sport and "friluftsliv" at the Department of Education and Sport Science at the University of Stavanger. He has been teaching BA students in outdoor education for many years and has research interests in increasing students' learning outcome and in outdoor leadership.

Sindre M. Dyrstad is a professor in sports science and head of the Public Health Department at the University of Stavanger. He has extensive experience in outdoor education and a strong research interest in increasing students' learning outcome.

\section{References}

Beames, S., \& Brown, M. (2016). Adventurous learning: A pedagogy for a changing world. Routledge.

Bolton, G. (2010). Reflective practice: Writing and professional development (3rd ed.). Sage.

Carver, R. (2008). Theory for practice: A framework for thinking about experiential education. In K. Warren, D. Mitten, \& T. A. Loeffler (Eds.), Theory \& practice of experiential education (4th ed., pp. 149-158). Association for Experiential Education.

Dale, G. A., \& Wrisberg, C. A. (1996). The use of a performance profiling technique in a team setting: Getting the athletes and coach on the "same page". The Sport Psychologist, 10(3), 261-277. https://doi.org/10.1123/ tsp. 10.3.261

Dewey, J. (1938). Experience and education. For the 60th anniversary edition: KAPPA DELTA PI.

Dreyfus, S. E., \& Dreyfus, H. L. (1980). A five-stage model of the mental activities involved in directed skill acquisition.

Enoksen, E., \& Lynch, P. (2018). Learning leadership: Becoming an outdoor leader. Fournal of Adventure Education and Outdoor Learning, 18(2), 176-188. https://doi.org/10.1080/14729679.2017.1391105

Field, A. (2013). Discovering statistics using IBM SPSS statistics: And sex and drugs and rock ' $n$ ' roll (4th ed.). Sage.

Faarlund, N. (1974). Friluftsliv: Hva - hvorfor - hvordan [Friluftsliv: What - Why - How]. Høyfjellsskolen norsk alpincenter.

Faarlund, N. (2003). Friluftsliv: Hva - hvorfor - hvordan [Friluftsliv: What - Why - How]. (Digital edition, L. Verket, Ed.). www.naturliv.no.

Graham, J. (1997). Outdoor leadership: Technique, common sense E् self-confidence. The Mountaineers Books.

Hallandvik, L., Andresen, M. S., \& Aadland, E. (2017). Decision-making in avalanche terrain: How does assessment of terrain, reading of avalanche forecast and environmental observations differ by skiers' skill level? Fournal of Outdoor Recreation and Tourism, 20, 45-51. https://doi.org/10.1016/j.jort.2017.09.004

Hattie, J. (2012). Visible learning for teachers: Maximizing impact on learning. Routledge.

Hattie, J., \& Timperley, H. (2007). The power of feedback. Review of Educational Research, 77(1), 81-112. https://doi.org/10.3102/003465430298487

Høyem, J. (2010). Vi graver oss ned i friluftslivsfagets didaktikk [Going into greater depth about Norwegian outdoor education]. Norsk pedagogisk tidsskrift, (1), 67-78. 


\section{Learning leadership in outdoor education}

Kolb, D. A. (1984). Experiential learning: Experience as the source of learning and development. Prentice-Hall.

Martin, B., Breunig, M., Wagstaff, M., \& Goldenberg, M. (2017). Outdoor leadership: Theory and practice (2nd ed.). Human Kinetics.

Martin, B., Cashel, C., Wagstaff, M., \& Breunig, M. (2006). Outdoor leadership: Theory and practice. Human Kinetics.

Norton, C. L., Russell, A., Wisner, B., \& Uriarte, J. (2011). Reflective teaching in social work education: Findings from a participatory action research study. Social Work Education, 30(4), 392-407. https://doi.org/ 10.1080/02615479.2010.500658

Paisley, K., Furman, N., Sibthorp, J., \& Gookin, J. (2008). Student learning in outdoor education: A case study from the national outdoor leadership school. The fournal of Experiential Education, 30(3), 201-222. https:// doi.org/10.1177/105382590703000302

Priest, S., \& Gass, M. A. (2018). Effective leadership in adventure programming (3rd ed.). Human Kinetics.

Sibthorp, J. (2003). Learning transferable skills through adventure education: The role of an authentic process. Fournal of Adventure Education and Outdoor Learning, 3(2), 145-157. https://doi.org/10.1080/ 14729670385200331

Sibthorp, J., Paisley, K., \& Gookin, J. (2007). Exploring participant development through adventure-based programming: A model from the national outdoor leadership school. Leisure Sciences, 29(1), 1-18. https:// doi.org/10.1080/01490400600851346

Statistic Norway. (2020). Idrett og friluftsliv, levekårsundersøkelsen [Sports and outdoor life, survey about living conditions]. Statistic Norway. https://www.ssb.no/kultur-og-fritid/idrett-og-friluftsliv/statistikk/idrett-ogfriluftsliv-levekarsundersokelsen

Tannenbaum, R., \& Schmidt, W. H. (1973). How to choose a leadership pattern. Harvard Business Review, 51(3), 162.

Tordsson, B. (2014). Perspektiv på friluftslivets pcedagogik [Perspectives of pedagogical friluftsliv] (2nd ed.). Books on Demand.

Vigane, Å., \& Sæther, E. (2020). Norwegian friluftsliv: History, cultural practice and values. In P.Vidal-González (Ed.), Hiking in European mountains: Trends and horizons De Gruyter Studies in tourism (Vol. 3, pp. 15-34). Walter De Gruyter.

Vikene, O. L., Vereide, V., \& Hallandvik, L. (2019). Ledelse og læring i friluftsliv [Leadership and learning in friluftsliv]. In A. Horgen, M. L. Fasting, T. Lundhaug, L. I. Magnussen, \& K. Østrem (Eds.), Ute! Friluftsliv - pedagogiske, historiske og sosiologiske perspektiver [Outside: Friluftsliv - pedagogical, historical and sociological perspectives]. Fagbokforlaget.

Wagstaff, M., \& Cashel, C. (2008). Paul Petzoldt's perspective: The final 20 years. In D. Mitten, T. A. Loeffler, \& K. Warren (Eds.), Theory $\mathcal{E}$ practice of experiential education (4th ed.). Association for Experiential Education.

Wenger, E. (2004). Praksisfellesskaber: Lering, mening og identitet [Community of practice: Learning, meaning and identity]. Reitzel.

Yukl, G. A. (1989). Leadership in organizations (2nd ed.). Prentice-Hall.

Yukl, G. A. (2010). Leadership in organizations (7th ed.). Pearson Education.

Yukl, G. A. (2013). Leadership in organizations (8th ed.). Pearson. 